\title{
Insider Trading after Repurchase Tender Offer Announcements: Timing versus Informed Trading
}

\author{
Henock Louis, Amy X. Sun, and Hal White*
}

\begin{abstract}
Abnormally high net insider selling is commonly observed after repurchase tender offer (RTO) announcements although, on average, firms experience positive abnormal returns in the years after the repurchases. We explore two potential explanations: liquidity trade timing and informed trading. Consistent with the notion that fixed price RTOs are more likely than Dutch-auction RTOs to signal undervaluation, the results suggest that insider selling after fixed price RTO announcements are driven largely by insiders who time their trades with the repurchase announcements. In contrast, selling after Dutch-auction RTOs seems to be driven primarily by informed traders who exploit mispricing associated with the repurchase announcements.
\end{abstract}

The last two decades have seen a proliferation of stock repurchases. Stefan Selig, ViceChairman of Bank of America Securities, observes that "repurchasing stock is one of the most frequently discussed corporate finance topics in boardrooms today" (Henry, 2004). ${ }^{1}$ Although firms repurchase shares for various reasons, the most commonly cited explanation in the academic literature is signaling (Bhattacharya, 1979; Dann, 1981; Vermaelen, 1981, 1984; Asquith and Mullins, 1986; Ofer and Thakor, 1987; Constantinides and Grundy, 1989; Lane, Sarker, and Wansley, 1989; Lakonishok and Vermaelen, 1990; Comment and Jarrell, 1991; Dann, Masulis, and Mayers, 1991; Hausch and Seward, 1993; Persons, 1997; D’Mello and Shroff, 2000). ${ }^{2}$ Consistent with the signaling hypothesis, firms engaging in repurchase tender offers (RTOs) experience, on average, very positive repurchase announcement abnormal returns (Dann, 1981; Comment and Jarrell, 1991) and post-repurchase announcement long-term abnormal returns (Peyer and Vermaelen, 2008). Given the large average post-repurchase long-term abnormal returns, it is puzzling that insiders engage in abnormally high selling activities in the quarter after the RTO

This paper benefits from comments by an anonymous referee, Walid Al-Issa, Lloyd Blenman, Steven Huddart, Brian Miller, and Karl Muller. We thank Christine Cheng and Kristy Schenck for their valuable assistance in collecting executive ownership data from proxy statements.

${ }^{*}$ Henock Louis is an Associate Professor of Accounting at Pennsylvania State University in University Park, PA. Amy X. Sun is an Assistant Professor of Accounting at Pennsylvania State University in University Park, PA. Hal White is an Assistant Professor of Accounting at the University of Michigan in Ann Arbor, MI.

\footnotetext{
1 “According to Standard \& Poor's, repurchase among companies in the S\&P 500 index soared 91\% during the first quarter of 2005, and by $64 \%$ for the 12 months ended March 31" (Kaye, 2005). Repurchases have become so popular that it appears "that every other company on Wall Street is announcing a share buyback" (Richard Gibbons, The Motley Fool, September 16, 2005).

${ }^{2}$ These reasons include signaling as well as nonsignaling purposes such as distribution of excess cash (Brennan and Thakor, 1990), reduction of agency costs (Grullon and Michaely, 2004), financing of option plans (Kahle, 2002), expropriation of creditors (Maxwell and Stephens, 2003), earnings management (Grullon and Ikenberry, 2000; Hribar, Johnson, and Jenkins, 2006), and maximization of employee stock option value (Jolls, 1998).
} 
announcements (Pettit, Ma, and He, 1996). The purpose of this paper is to test two alternative hypotheses for this somewhat counterintuitive trading pattern. Under the first hypothesis, insiders trading for liquidity reasons time their selling activities with the repurchase announcement to minimize potential undervaluation, thereby maximizing their selling price. Under the second hypothesis, insiders trading on their private information sell shares in response to overpricing due to market misinterpretation of the degree to which certain repurchase announcements act as signals of undervaluation.

As Fried (2001) suggests, managers planning to sell shares for nonspeculative reasons might time their trades with repurchases in an effort to maximize the selling price of their shares. The idea is that repurchases are generally undertaken when firms are undervalued (Brav et al., 2005). Accordingly, the announcement of an RTO is, on average, associated with a substantial increase in price. As such, insiders, through the repurchase announcement, are able to mitigate the effects of undervaluation before they sell.

RTOs provide managers with an additional opportunity to benefit from insider trading. As Fried (2000) points out, an RTO is a unique setting to examine insider trading in that it allows insiders to be somewhat sheltered from litigation since the "materiality" threshold for information disclosure is not as strong. ${ }^{3}$ As such, RTOs can provide incentives for insiders to take advantage of their private information. For example, if investors misinterpret nonsignaling repurchases as signals of managerial optimism, the unsubstantiated increase in price would allow insiders to exploit the mispricing with less risk of punishment.

Consistent with Pettit, Ma, and He (1996), we find that managers sell substantial amounts of shares after RTO announcements. ${ }^{4}$ In the quarter immediately after the announcements, the net amount of shares sold by insiders is, on average, $1.96 \%$ of the shares outstanding as compared to quarterly averages of $0.02 \%$ and $0.17 \%$ for the four quarters preceding and the four quarters subsequent to the quarter after the repurchase announcement, respectively. ${ }^{5}$ We also find a significantly negative association between net insider selling and both operating and stock performances over the three years after the repurchase announcement, suggesting that managers take advantage of their private information. However, we find some evidence of insider selling even when a firm subsequently experiences superior performance, suggesting that not all insider trading after RTO announcements is driven by informed trading. Although we find that insiders sell large amounts of shares in firms that subsequently perform very poorly, we find no evidence that they buy shares in firms that subsequently perform well. A potential explanation for the lack of insider buying is that managers who are looking for opportunities to buy undervalued shares would have no incentive to signal the undervaluation (e.g., using an RTO) before they buy.

\footnotetext{
${ }^{3}$ Fried (2000) states, "It is important to emphasize that insiders' use of RTOs to exploit inside information does not necessarily violate the securities laws. These laws impose liability on insiders (as well as the corporation itself) if they buy or sell stock without disclosing 'material' inside information. However, internal projections and other forms of 'soft' information are not considered legally material, even if the information would be extremely valuable to investors. As a result, insiders are free to conduct RTOs and trade in the market without disclosing a wide range of valuable, but 'submaterial' information."

${ }^{4}$ We focus on RTO announcements as opposed to open market repurchase announcements due to the substantial impact that RTO announcements have on stock price and the difference in the signaling power of the two types of tender offers (Dutch vs. fixed price repurchases). In addition, contrary to open market repurchases, repurchase tender offers entail substantial costs, involve outside parties, and are generally carried out, which is more consistent with credible signaling (Nayar, Singh, and Zebedee, 2008). Also, from a practical perspective, open market repurchases usually take several months to several years to complete whereas repurchase tender offers are usually completed within a month (Fried, 2000).

${ }^{5}$ Note that trading in the months immediately following repurchase announcements may be optimal for informed traders who want to distance their selling as much as possible from forthcoming disappointing earnings and/or returns.
} 
Finally, we partition the sample into the two types of RTOs: 1) fixed price and 2) Dutch auction tender offers. In a fixed price tender offer, the purchase price includes a premium set by the manager whereas in a Dutch auction tender offer, the manager offers a range to investors to bid for tendering with the maximum premium generally similar to the average fixed price premium (Fried, 2000). Note that the Dutch auction repurchase price is determined by the most pessimistic investors instead of the managers. Fried (2000) suggests that most Dutch auction tender offers are conducted for purposes other than signaling (Comment and Jarrell, 1991; Lee, Mikkelson, and Partch, 1992; Louis and White, 2007). He also argues that insiders can potentially extract more rents from shareholders using Dutch auction tender offers since the signal conveyed by a Dutch auction tender offer is a noisier signal of firm value than that conveyed by a fixed price tender offer. Therefore, investors are more likely to commit valuation errors in response to announcements of Dutch auction tender offers.

We find striking differences between the post-repurchase announcement insider trading patterns of the fixed price tender offer firms and those of the Dutch auction tender offer firms. The significantly negative association between net insider selling and future long-term performance documented for the full sample is driven by the firms engaging in Dutch auction tender offers. In contrast, we find no evidence that insider selling after fixed priced tender offer announcements is significantly associated with future performance, even though insider selling is generally high after fixed priced tender offers.

Overall, the evidence suggests that insider selling after fixed price tender offer announcements is likely driven by liquidity traders who time the repurchase announcements with their selling to maximize their selling price while selling after Dutch auction tender offers seems to be driven largely by insiders using litigation relief to take advantage of mispricing. Our inference related to Dutch auction tender offers is based particularly on the observation that net insider selling after Dutch auction repurchase announcements is concentrated mainly among firms that subsequently perform poorly. In addition, this pattern is observed almost exclusively in the quarter after the repurchase announcement. Our inference related to fixed price tender offers is supported by the observation that: 1) the average percentage of shares repurchased and the market reaction to the repurchase announcement are significantly larger for fixed price tender offers than for Dutch auction tender offers and 2) there is a strong concentration of insider selling in the quarter after fixed price tender offer announcements, although there is no indication that the selling is related to future performance.

The remainder of the study is organized as follows. The next section discusses the potential association between signaling, future performance, and insider trading. Section II explains how we measure our main variables. Section III describes the sample and provides some descriptive statistics. Section IV analyzes insider trading around RTO announcements. Section V analyzes the association between insider trading and future performance. The study concludes in Section VI.

\section{Signaling, Future Performance, and Insider Trading}

Consistent with the signaling hypothesis, prior studies find that the average abnormal return around RTOs is positive (Comment and Jarrell, 1991; Louis and White, 2007). In line with these prior studies, we find average abnormal returns of about $4.78 \%(24.24 \%)$ for our sample over the one (three) year(s) after the repurchase announcement month. However, we also observe that a very large number of repurchasing firms experience negative long-term abnormal returns. About $54 \%(50 \%)$ of our sample firms experience negative abnormal returns over the one (three) year(s) 
after the repurchase announcement month. Thus, assuming that a repurchase is a positive signal because the average long-term abnormal return is positive could be misleading.

We contend that investors could sometimes interpret nonsignaling repurchases as signals of managerial optimism that temporarily inflate the stock prices. The mispricing could then allow insiders to exploit their private information about their firms' future performance by selling shares at the inflated prices. We do not assume that investors are necessarily naïve. In fact, investors likely interpret the repurchase announcement correctly as a signal of managerial optimism because irrespective of the purpose of the repurchase, managers are more likely to undertake a repurchase when they believe that the shares are underpriced. We believe, however, that investors cannot always determine when, and to what degree, a repurchase is associated with favorable private information about a firm's future performance. Therefore, investors could occasionally falsely interpret nonsignaling repurchases as positive signals. ${ }^{6}$ We contend that repurchases will create trading opportunities for insiders as long as investors are mistaken, at least some of the time, about the information content of the repurchases. ${ }^{7}$

Comment and Jarrell (1991) argue that Dutch auction tender offers are less likely than fixed price tender offers to signal positive private information as managers structure Dutch auction tender offers to minimize the purchasing price instead of revealing their private beliefs about firm value (Gay, Kale, and Noe, 1991; Lee, Mikkelson, and Partch, 1992; Persons, 1994; Fried, 2000; Grullon and Ikenberry, 2000; Louis and White, 2007). ${ }^{8}$ Furthermore, Fried (2000) argues that Dutch auction repurchases are more susceptible to mispricing as the repurchase price represents a noisier signal of firm value. Accordingly, we hypothesize that informed insider selling is more likely to be associated with Dutch auction tender offers as managers take advantage of mispricing due to the inability of investors to accurately determine the strength of the repurchase signal. In contrast, we conjecture that managers interested in nonspeculative (liquidity) trading will time their trades with fixed price repurchases in an attempt to mitigate any potential undervaluation by signaling firm value before they sell their shares.

Although we expect to find informed selling after Dutch auction tender offers, we have no such expectation for fixed price tender offers. In a Dutch auction tender offer, the repurchase price is determined by investors. Managers then have opportunities to exploit their private information any time the market overreacts to the repurchase announcement. In contrast, in a fixed price

\footnotetext{
${ }^{6}$ For instance, following a Dutch auction tender offer announcement by Schlumberger Ltd., the chairman of its board, Euan Baird, stated, "The company considers that its $\$ 1.6$ billion of cash and short-term investments less debt outstanding exceeds foreseeable needs. We believe that the best use of our excess liquidity at the current time is to purchase our own common stock. The remaining net liquidity, in addition to our anticipated cash flow from ongoing operations, will fully satisfy our future business requirements." However, investors and the financial press interpreted the repurchase announcement as a positive signal about firm value. Suzanne Cook, first vice president and oil-service analyst at Merrill Lynch \& Co. in Denver called the repurchase announcement "a signal that company thinks its stock is a good value" (Hyatt, 1988). While her assessment may be correct in this particular case, the general tendency to interpret repurchases as favorable signals makes it plausible that the market will react positively even when the repurchase is conducted for purposes other than signaling. The article, "Insider's View: Firms Planning Buybacks Make a Profitable Bet” (Opdyke, 1998), is also a good illustration of the extent to which analysts and the financial press promote the idea that repurchases, in general, signal favorable managerial information.

${ }^{7}$ We do not exclude the possibility that managers may purposely provide false signals. Surveys of top executives suggest that managers often attempt to mislead investors. Higher earnings per share is often cited by managers, investment bankers, and analysts as a reason for, and a major benefit of, stock repurchases (Grullon and Ikenberry, 2000; Graham, Harvey, and Rajgopal, 2005).

${ }^{8}$ In fact, it is reported that the first Dutch auction tender offer was conducted by Todd Shipyards in 1981 whereby Bear Stearns advised the company to structure the transaction as a Dutch auction with the sole intent of reducing the repurchase price. Todd Shipyards ended up repurchasing the shares at $\$ 26.50$ or less instead of the $\$ 28$ it had originally planned to pay in a fixed price tender offer (Fried, 2000).
} 
repurchase, the price is set by managers. Therefore, fixed price tender offers leave managers more exposed to claims of false signaling. Hence, even if the managers want to send false signals, they will be less likely to use fixed price tender offers to do so. Again, we do not assume that managers necessarily choose to send false signals through Dutch auction tender offers. It is sufficient for investors to falsely interpret some nonsignaling repurchases as positive signals for our conjecture to hold.

\section{Variable Definition and Measurement}

\section{A. Measuring Insider Trading}

We express insider trading as a percentage of shares outstanding. Our definition of insider includes current officers and directors. We do not restrict our analysis to the top executives, as any insider who has private information about future prospects can benefit from that information. We also assume that managers below the top executive level are likely to be aware of the plans to conduct the repurchases and may even be involved in the preparation of the offers. Hence, these managers are also likely to time their trading with the repurchase. In addition, although the top executives are likely to be privy to broader and more reliable information and are the ultimate decision makers, they are also likely to have more concerns about the legal consequences of their trades. Therefore, it is not clear that top executives will necessarily trade more on their incremental private information. Because insiders who are not current officers or directors are less likely to be privy to private information, we exclude trades by affiliated persons, affiliates of investment advisors, beneficial owners of the company's securities, beneficial owners as custodians, beneficial owners as trustees, investment advisors, shareholders, indirect shareholders, or chairman emeritus who is neither an officer nor a director.

\section{B. Measuring Long-Term Operating Performance}

To measure long-term operating performance, we first compute the average quarterly return on assets (ROA) over the year (four quarters) prior to the repurchase announcement and the average quarterly ROA over the three years (12 quarters) after the repurchase announcement. We calculate the pre-repurchase announcement average quarterly ROA using only one year to get the most recent average while maintaining a reasonable length of time for calculations. If a firm has a missing value on Compustat, we use the average ROA for the reported quarters as the ROA for the missing quarter. Next, we adjust the average quarterly ROA for industry effects by subtracting the (two-digit SIC code) industry median of the average quarterly ROA. Finally, we compute the change in the industry-adjusted ROA as the difference between the average quarterly industry-adjusted ROA over the three years after the repurchase announcement (Quarter +1 to Quarter +12 ) and the average quarterly industry-adjusted ROA over the year immediately before the repurchase announcement (Quarter -4 to Quarter -1 ), where Quarter 0 is the quarter immediately after the repurchase announcement. The timing of the quarters is based on the earnings announcement dates rather than the end of the fiscal quarter.

\section{Measuring Long-Term Abnormal Stock Returns}

We measure long-term abnormal stock returns using the benchmark return adjustment procedure of Daniel et al. (1997). We use a match-portfolio approach to compute the long-term abnormal returns instead of a match-firm approach particularly because our sample is small. 
The match-portfolio approach enables us to match on multiple dimensions without losing any observation. Daniel et al.'s (1997) match-portfolio procedure controls for the effects of size, book-to-market, and return momentum.

First, we assign each stock that has book value of equity on Compustat and price and shares outstanding on CRSP to a size quintile (using NYSE size quintile breakpoints). Within each size quintile, we rank the stocks based on their industry-adjusted book-to-market ratios and assign them to book-to-market quintiles, yielding a total of 25 size- and book-to-market-sorted fractiles. We then sort them into quintiles within each of the 25 size- and book-to-market fractiles based on the prior 12-month stock return. This results in a total of 125 fractiles. Then, we compute a monthly value-weighted buy-and-hold return for each of the 125 fractile portfolios. The benchmark portfolios are reconstructed annually at the end of June. The monthly returns for each stock and the benchmark portfolio monthly returns are then compounded over the 12 and 36 months after the repurchase announcement month. The abnormal return for each stock is the difference between the stock's buy-and-hold return and its benchmark portfolio return. Delisting returns are included if available. If a stock disappears from CRSP, we assume the stock earns zero abnormal returns for the missing months.

\section{Sample Selection and Descriptive Statistics}

\section{A. Sample Selection}

The study covers RTOs by US companies that were announced from January 1984 to December 2003, inclusively. We start the sample in 1984 since we need insider trading data for four quarters prior to the repurchase announcement and have insider trading data starting only in 1983. We end the sample in 2003 as we need Compustat earnings and CRSP return data to compute performance over the three years after the repurchase announcement. The sample of stock repurchases is obtained from the Security Data Company's (SDC) online database of domestic acquisitions.

A transaction is included in the sample if it satisfies the following criteria: 1) the repurchase is a nondefensive tender offer, 2) the proportion of shares outstanding acquired in the transaction is available on SDC, 3) insider trading is available on the Thompson Insider Filing Feed database, 4) return data are available from CRSP, and 5) net income, total assets, price, common shares outstanding, and book value of common equity are available on Compustat. We eliminate those observations that involve repurchases from odd lot holders. We also require that the amount of shares repurchased be at least $2 \%$ of the shares outstanding. The final sample has 274 RTOs including 163 Dutch auction tender offers and 111 fixed price tender offers.

\section{B. Descriptive Statistics}

Table I reports descriptive statistics. Firms engaging in fixed price tender offers tend to be larger, with an average market value (SIZE) of $\$ 1,172$ million as compared to an average of $\$ 810$ million for firms engaging in Dutch auction tender offers. However, the difference in the average size of the two groups of firms is not statistically significant. Firms engaging in Dutch auction tender offers tend to have higher book-to-market ratios $(B M)$ (an average of 0.71 as compared to 0.59 for firms engaging in fixed price tender offers); however, the difference is not statistically significant. Firms engaging in Dutch auction tender offers repurchase a significantly lower percentage of shares (SHR_REP) (an average of $13.54 \%$ as compared to $25.27 \%$ for firms engaging in fixed price tender offers). 


\section{Table I. Descriptive Statistics}

SIZE is the market value of equity (in millions) at the beginning of the fiscal quarter preceding the repurchase announcement; $B M$ is the ratio of book-to-market value of equity at the beginning of the fiscal quarter preceding the repurchase announcement; $S H R \_R E P$ is the percentage of shares acquired in the repurchase; $A D J \_R O A M 1$ is the average quarterly industry-adjusted return on assets (ROA) over the year immediately before the repurchase announcement (Quarter -4 to Quarter -1 ), Quarter 0 being the quarter immediately after the repurchase announcement; $A D J \_R O A 3$ is the average quarterly industry-adjusted ROA over the three years after the repurchase announcement (Quarter +1 to Quarter +12 ), Quarter 0 being the quarter immediately after the repurchase announcement; $\triangle A D J \_R O A 3$ is the average quarterly industry-adjusted ROA over the three years after the repurchase announcement minus the average quarterly industry-adjusted ROA over the year immediately before the repurchase announcement ( $\left.A D J \_R O A 3-A D J \_R O A M 1\right) ; C A R$ is the market-adjusted return over the three days centered on the repurchase announcement date; Negative_CAR is a binary variable taking the value one if $C A R$ is negative and zero otherwise; $L T A B R E T 1$ is the abnormal return over the year subsequent to the repurchase announcement month; Negative_LTABRET1 is a binary variable taking the value one if LTABRET1 is negative and zero otherwise; LTABRET3 is the abnormal return over the three years subsequent to the repurchase announcement month; and Negative_LTABRET3 is a binary variable taking the value one if $L T A B R E T 3$ is negative and zero otherwise. We report Satterthwaite's $t$-values assuming that the variances for Dutch auction and fixed price tender offers are unequal.

\begin{tabular}{|c|c|c|c|c|}
\hline & $\begin{array}{c}(1) \\
\text { Full Sample } \\
(N=274)\end{array}$ & $\begin{array}{l}(3) \\
\text { Dutch Auction } \\
(N=163)\end{array}$ & $\begin{array}{c}(4) \\
\text { Fixed Price } \\
(N=111)\end{array}$ & $\begin{array}{c}(3-4) \\
\text { Differences in Means } \\
\text { and Associated } \\
t \text {-statistics }\end{array}$ \\
\hline \multicolumn{5}{|l|}{ Firm characteristics } \\
\hline SIZE & 956.31 & 809.52 & $1,171.86$ & -363.34 \\
\hline$B M$ & 0.66 & 0.71 & 0.59 & 0.12 \\
\hline \multicolumn{5}{|l|}{ Size of the transaction } \\
\hline$S H R \_R E P(\%)$ & 18.30 & 13.54 & 25.27 & $-11.73^{* * *}$ \\
\hline \multicolumn{5}{|l|}{ Earnings performance } \\
\hline$A D J \_R O A M 1(\%)$ & 0.82 & 0.98 & 0.59 & 0.39 \\
\hline$A D J \_R O A 3$ (\%) & 0.84 & 0.95 & 0.68 & 0.27 \\
\hline$\triangle A D J \_R O A 3(\%)$ & 0.05 & 0.19 & -0.16 & 0.35 \\
\hline \multicolumn{5}{|l|}{ Stock performance } \\
\hline CAR $[-1+1](\%)$ & 11.12 & 9.14 & 14.03 & $-4.89^{* * *}$ \\
\hline Negative_CAR & 0.09 & 0.09 & 0.09 & 0.00 \\
\hline LTABRET1 (\%) & 4.86 & 7.47 & 1.02 & 6.45 \\
\hline Negative_LTABRET1 & 0.54 & 0.50 & 0.60 & -0.11 \\
\hline LTABRET3 (\%) & 24.36 & 20.25 & 30.41 & -10.16 \\
\hline Negative_LTABRET3 & 0.50 & 0.49 & 0.50 & -0.01 \\
\hline
\end{tabular}

${ }^{* * *}$ Significant at the 0.01 level.

We report the earnings performance around the repurchase announcement. The average quarterly industry-adjusted ROA over the year immediately before the repurchase announcement (ADJ_ROAM1) is $0.82 \%$, and the average quarterly industry-adjusted ROA over the three years after the repurchase announcement $\left(A D J \_R O A M 3\right)$ is $0.84 \%$. The average change in the quarterly industry-adjusted ROA over the three years after the repurchase announcement ( $\triangle A D J \_R O A M 3$ ) is $0.05 \%$. These results are consistent with Lie and McConnell (1998). Repurchasing firms outperform their industry peers both before and after the repurchases. There is no evidence that the operating performance measures are statistically different across the two groups of firms. 
We also report the market performance of the repurchasing firms. Consistent with the signaling hypothesis, firms experience large cumulative abnormal returns $(C A R)$ around the repurchase announcement. Also, consistent with the conjecture that Dutch auction tender offers are less likely than fixed price tender offers to signal positive private information, the average $C A R$ is significantly lower for Dutch auction tender offers than for fixed price tender offers $(9.14 \%$ vs. $14.03 \%$ ). The average $C A R$ is significantly positive for both Dutch auction tender offers and fixed price tender offers ( $p$-values $=0.000)$. Consistent with Peyer and Vermaelen (2008), we find large abnormal returns over the years subsequent to the repurchase announcements. The average three-year abnormal return after the repurchase announcements (LTABRET3) is substantial for both types of repurchases, although it is about $50 \%$ higher for fixed price tender offers $(20.25 \%$ for firms engaging in Dutch auction repurchases vs. $30.41 \%$ for those engaging in fixed price repurchases). Future stock returns are positive, but there is no evidence of improvement in future earnings. Therefore, if there is a signal associated with the repurchases, it might be that "the above average operating performance of the repurchasing firms will continue longer than might otherwise have been expected" (Lie and McConnell, 1998).

\section{Insider Trading around Stock Repurchase Announcements}

\section{A. Trading by Management (Broadly Defined) around RTO Announcements}

We separately analyze insider net selling, insider selling, and insider buying after the tender offer repurchase announcements. Survey data by Bettis, Coles, and Lemmon (2000) indicate that many firms have policies that restrict insiders' trading around some important corporate events. Therefore, a priori, the timing of the potential insider trading is unclear. Hence, we report insider trading not only in the quarter that immediately follows the repurchase announcement (Quarter 0), but also over the four quarters after the quarter that immediately follows the RTO announcement (i.e., Quarter +1 through Quarter +4 ). For the sake of comparison, we also report insider trading over the four quarters prior to the repurchase announcement (i.e., Quarter -4 through Quarter -1). The timeline is presented below.

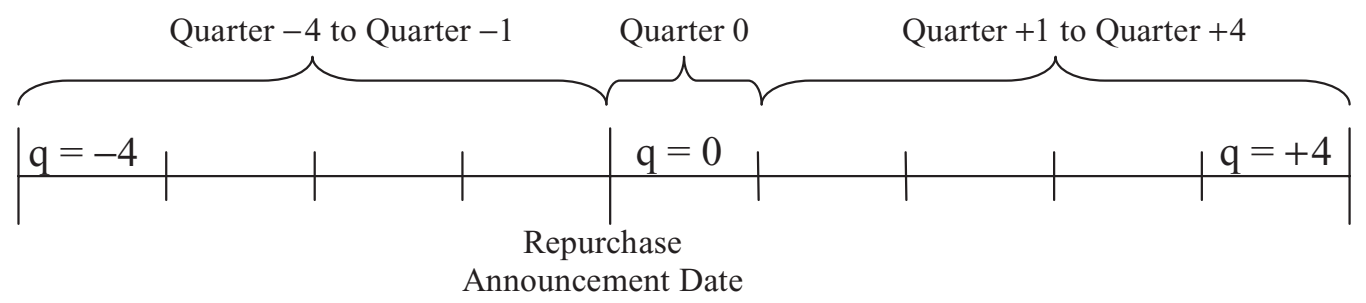

The pattern of insider trading over the quarters around the repurchase announcements is presented in Table II. The average net selling over Quarter -4 through Quarter -1 is $0.02 \%$ of total shares outstanding. The percentage dramatically increases to $1.96 \%$ in Quarter 0 then falls back to $0.17 \%$ over Quarter +1 through Quarter +4 . These results are driven by insider selling (as opposed to insider buying). The average insider selling over Quarter -4 through Quarter -1 is $0.15 \%$ of total shares outstanding. The percentage dramatically increases to $2.29 \%$ over Quarter 0 then falls back to $0.37 \%$ over Quarter +1 through Quarter +4 . Finding a large amount of insider selling is quite interesting considering that RTOs are generally thought to signal better future prospects (Comment and Jarrell, 1991). The average number of shares (as a percentage of total shares outstanding, excluding options) held by executives is $9.43 \%$ for our sample firms that 


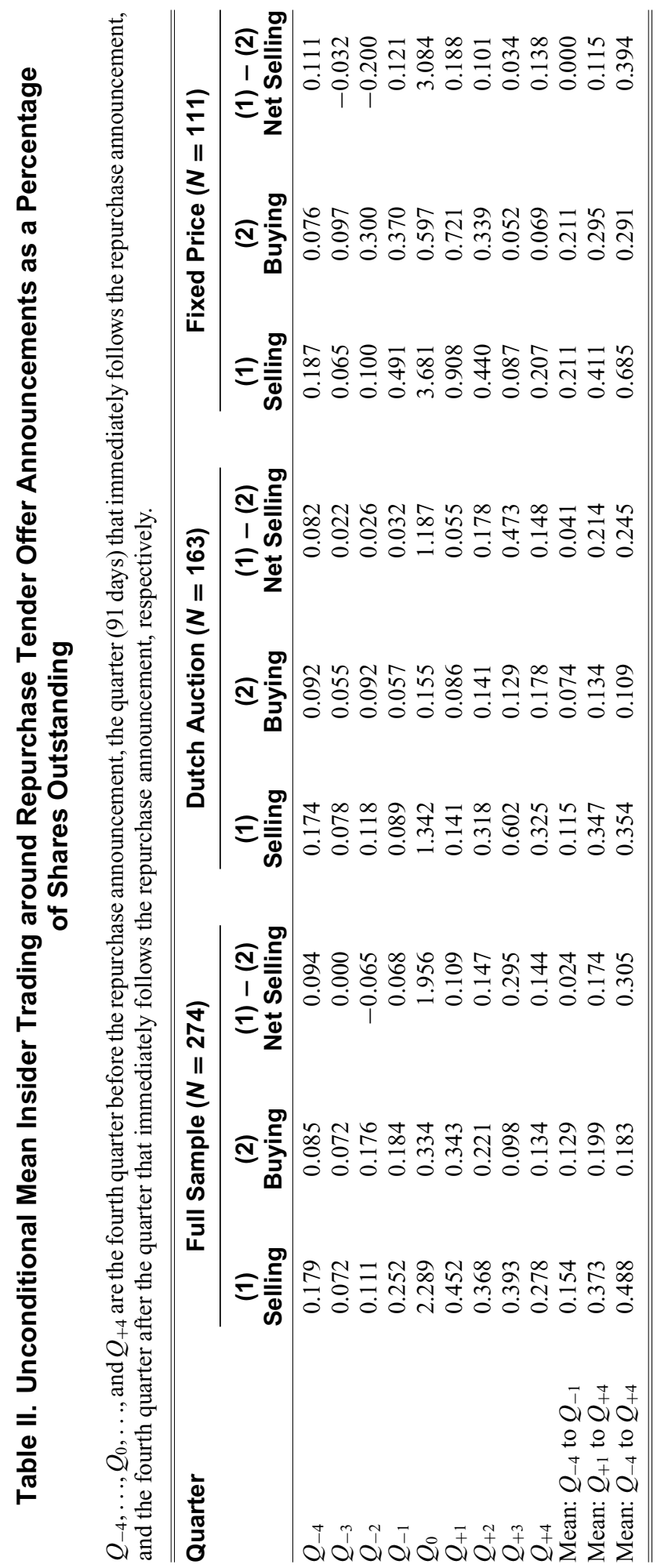


have ownership data on Execucomp or the Electronic Data Gathering, Analysis, and Retrieval (EDGAR) archives. Lakonishok and Lee (2001) demonstrate that the average number of shares sold by managers per year as a percentage of shares outstanding from 1975 to 1995 is about $0.9 \%$ (or $0.22 \%$ per quarter). The average increases to $1.3 \%$ per year (or about $0.33 \%$ per quarter) when they include selling by large shareholders and "others." In view of these numbers, the $2.29 \%$ of shares sold by insiders that we observe in the quarter immediately following the repurchase announcement is quite large.

We also compare the pattern of net insider selling for Dutch auction tender offers with that of fixed price tender offers. There are substantial increases in insider selling in the quarter immediately following the repurchase announcement for both Dutch auction and fixed price tender offer repurchases. However, net insider selling is more than twice as large for fixed price tender offers (about $3.08 \%$ of shares outstanding as opposed to $1.19 \%$ for Dutch auction tender offers). Again, these results are driven by the selling transactions. ${ }^{9}$

\section{B. Number of Trades by Management around RTO Announcements}

We express insider trading as a percentage of shares outstanding. Some studies use the number of transactions as an alternative measure of insider trading; however, one serious disadvantage of such a measure is that it gives the same weight to a $\$ 1,000$ transaction as it gives to a $\$ 100$ million transaction. Nonetheless, to assess the robustness of our results, we also compute the net number of sales transactions (number of sales transactions minus number of buy transactions) around the repurchase announcement. Untabulated results using the net number of sales transactions are consistent with our results using the net percentage of outstanding shares sold. For Dutch auction tender offers, the average net number of sales transactions over Quarter -4 through Quarter -1 is -0.21 . The number dramatically increases to 2.14 in Quarter 0 then falls back to 0.63 over Quarter +1 through Quarter +4 . For fixed price tender offers, the average net number of sales transactions over Quarter -4 through Quarter -1 is 0.47 . The number dramatically increases to 3.01 in Quarter 0 then falls back to 0.11 over Quarter +1 through Quarter +4 .

\section{Multivariate Analysis}

Rozeff and Zaman (1998) document that insider buying increases as stocks change from growth to value categories. Moreover, insiders are likely to sell a larger portion of the firm on personal accounts to satisfy their needs when the firm is small. Therefore, we model insider trading as a function of the stock repurchase, size, and book-to-market. More specifically, we use the following model:

$$
\begin{aligned}
N I T_{i, t}= & \alpha_{1} Q_{-3 i}+\alpha_{2} Q_{-2 i}+\alpha_{3} Q_{-1 i}+\alpha_{4} Q_{0 i}+\alpha_{5} Q_{+1 i}+\alpha_{6} Q_{+2 i}+\alpha_{7} Q_{+3 i}+\alpha_{8} Q_{+4 i} \\
& +\alpha_{9} \text { SIZE }_{i, t}+\alpha_{10} B M Q_{i, t}+\text { firm fixed effects }_{i}+e_{i, t},
\end{aligned}
$$

where $N I T_{t}$ is net insider trading (i.e., net selling) for Quarter $t$, with $t$ ranging from -4 to +4 and Quarter 0 being the quarter that immediately follows the repurchase announcement; $Q_{t}$ is an indicator variable taking the value one in Quarter $t$ and zero otherwise, with $Q_{0}$ representing the quarter that immediately follows the repurchase announcement; SIZE $Q_{t}$ is the size quintile for

\footnotetext{
${ }^{9}$ Our definition of insider includes current officers, directors, and controlling shareholders. However, restricting insider trading to trading by the top five executives, officers, and directors with substantial ownership and controlling shareholders or simply to trading by the top five executives does not qualitatively change the pattern that we document.
} 
Quarter $t$, where size is the market value of equity at the beginning of the fiscal quarter prior to calendar Quarter $t$ (the insider trading calendar quarter); and $B M Q_{t}$ is book-to-market quintile for Quarter $t$, where book-to-market is the ratio of common book equity to total market capitalization at the beginning of the fiscal quarter prior to calendar Quarter $t$ (the insider trading calendar quarter).

NIT, SIZEQ, and $B M Q$ are measured on a quarterly basis from Quarter $-4\left(Q_{-4}\right)$ to Quarter $+4\left(Q_{+4}\right)$. The average net insider trading for Quarter $-3, \ldots$ Quarter $0, \ldots$ and Quarter +4 is captured by the coefficients on $Q_{+3}, \ldots Q_{0}, \ldots$ and $Q_{+4}$, respectively. The average net insider trading for $Q_{-4}$ is captured in the firm fixed effects. The sample has 274 repurchases, however, because each repurchase is represented multiple times in the sample (from Quarter -4 to Quarter +4 ), Model 1 is estimated with 2,282 data points. We add an indicator variable for each firm (firm fixed effects) to control for potential cross-correlations. The parameters of the model are estimated for fixed price RTOs and Dutch auction RTOs using a pooled regression with interactive variables.

The results are presented in Table III. The results are similar to those reported in the univariate analysis. We find significant net insider selling in the quarter immediately following the repurchase announcement. There is no evidence of significant net insider selling in the surrounding quarters. Substantial insider selling takes place in the quarter immediately following the repurchase announcement for both types of RTOs, yet net insider selling is larger for fixed price tender offers. The results are qualitatively similar if we restrict insider trading to trading by the top five executives, officers, and directors with substantial ownership and controlling shareholders. To assess the potential effects of outliers, we also report results after winsorizing the top and bottom 1 percentiles of net insider selling. There is no evidence that the results are driven by outliers. After we winsorize the top and bottom 1 percentiles of net insider selling, the incremental effect of the repurchase announcement (captured by the coefficient on the indicator variable for the quarter immediately after the announcement) is slightly lower but more statistically significant.

We do not control for insider ownership in our main analysis since data on insider ownership are largely accessible starting in 1994. Nonetheless, to ensure that our results are not driven by the failure to control for ownership, we replicate the analysis for those firms that have executive ownership data available. Because we need ownership data prior to the repurchase announcement, the subsample of repurchases for this robustness analysis starts in 1995 . We first retrieve stock ownership data from Execucomp. We then hand collect data from the historical EDGAR archives on the Securities and Exchange Commission website for firms that do not have data on Execucomp. There are 136 RTOs (including 94 Dutch auction tender offers and 42 fixed price tender offers) that have available executive ownership data.

We obtain results similar to those in Table IV after including in the regression the total percentage of executive stock holdings prior to the repurchase. There is no evidence of significant net insider selling for the surrounding quarters. Substantial insider selling takes place in the tender offers; however, net insider selling is much larger for fixed price tender offers. Untabulated results indicate that for the 94 Dutch auction tender offers, the coefficients on $Q_{-3}, \ldots Q_{0}, \ldots$, and $Q_{+4}$ are $-0.05,-0.07,-0.02,1.49,0.04,0.06,0.06$, and 0.03 , respectively. For the 42 fixed price tender offers, the coefficients are $-0.11,-0.68,-0.91,3.53,0.28,-0.38,-0.32$, and 0.05 . The coefficients on $Q_{0}$ are both significant at the $1 \%$ level. The difference is also significant at the $1 \%$ level. The number of executives on the databases varies across firms, which could affect our results. To mitigate this problem, we also control for the average executive ownership in each firm and obtain qualitatively the same results. 


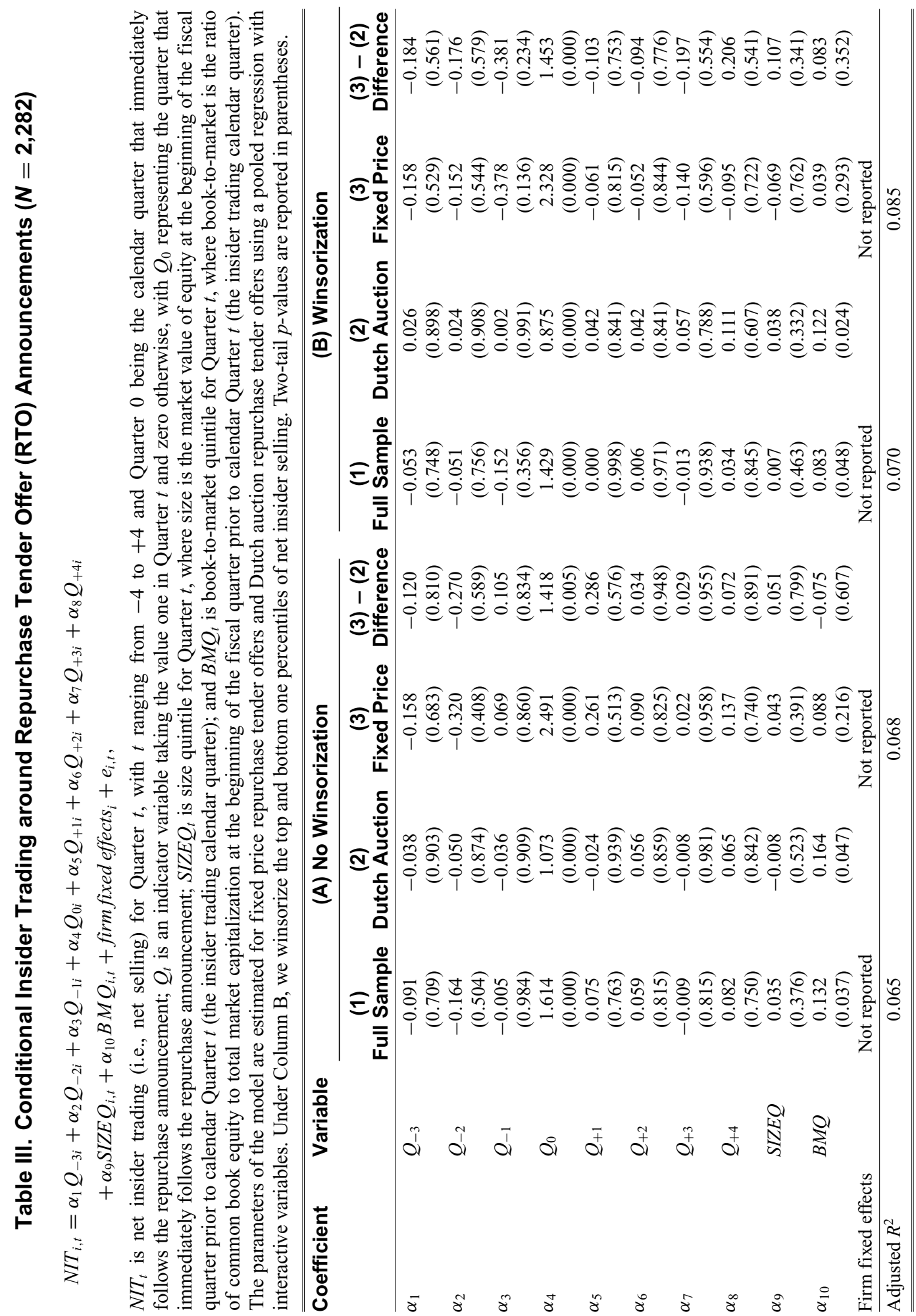




\section{Table IV. Mean Percentage of Net Insider Selling as a Function of Future Performance $(N=274)$}

This table presents the association between net insider selling in the quarters surrounding repurchase announcements and performance over the three years following the repurchase announcement month. Future performance is deemed "inferior," "neutral," or "superior" if it is in the lowest quintile, the middle three quintiles, or the highest quintile of the performance distribution. $\triangle A D J \_R O A 3$ and LTABRET3 are defined as in Table I. $Q_{-4}, \ldots, Q_{0}, \ldots$, and $Q_{+4}$ are the fourth quarter before the repurchase announcement, ..., the quarter ( 91 days) that immediately follows the repurchase announcement, ..., and the fourth quarter after the quarter that immediately follows the repurchase announcement, respectively.

\begin{tabular}{|c|c|c|c|c|c|c|}
\hline \multirow[t]{2}{*}{ Quarter } & \multicolumn{3}{|c|}{$\begin{array}{l}\text { Future Operating Performance } \\
\left(\triangle A D J \_R O A 3\right)\end{array}$} & \multicolumn{3}{|c|}{$\begin{array}{l}\text { Future Stock Performance } \\
\text { (LTABRET3) }\end{array}$} \\
\hline & $\begin{array}{l}\text { Inferior } \\
(N=54)\end{array}$ & $\begin{array}{c}\text { Neutral } \\
(N=166)\end{array}$ & $\begin{array}{l}\text { Superior } \\
(N=54)\end{array}$ & $\begin{array}{l}\text { Inferior } \\
(N=54)\end{array}$ & $\begin{array}{c}\text { Neutral } \\
(N=166)\end{array}$ & $\begin{array}{l}\text { Superior } \\
(N=54)\end{array}$ \\
\hline$\overline{Q_{-4}}$ & 0.024 & 0.084 & 0.193 & 0.071 & 0.043 & 0.274 \\
\hline$Q_{-3}$ & 0.056 & -0.027 & 0.028 & 0.038 & -0.004 & -0.024 \\
\hline$Q_{-2}$ & 0.049 & -0.149 & 0.078 & 0.086 & -0.139 & 0.009 \\
\hline$Q_{-1}$ & 0.054 & 0.128 & -0.104 & 0.035 & 0.133 & -0.100 \\
\hline$Q_{0}$ & 3.545 & 1.628 & 1.374 & 3.248 & 1.739 & 1.328 \\
\hline$Q_{+1}$ & 0.071 & 0.128 & 0.086 & 0.644 & -0.044 & 0.042 \\
\hline$Q_{+2}^{+1}$ & 0.228 & 0.031 & 0.421 & 0.395 & 0.055 & 0.181 \\
\hline$Q_{+3}$ & 1.347 & 0.018 & 0.095 & 0.001 & 0.462 & 0.078 \\
\hline$Q_{+4}$ & 0.221 & 0.115 & 0.156 & 0.221 & 0.097 & 0.212 \\
\hline Mean: $Q_{-4}$ to $Q_{-1}$ & 0.046 & 0.009 & 0.049 & 0.058 & 0.008 & 0.040 \\
\hline Mean: $Q_{+1}$ to $Q_{+4}$ & 0.467 & 0.073 & 0.190 & 0.315 & 0.143 & 0.128 \\
\hline Mean: $Q_{-4}$ to $Q_{+4}$ & 0.622 & 0.217 & 0.259 & 0.527 & 0.260 & 0.222 \\
\hline
\end{tabular}

\section{The Association between Insider Trading and Future Performance}

Next, we explore the managers' motivations for selling after RTOs. If insiders trade on their private information, then we expect their selling to be associated with the post-repurchase performance. Specifically, we anticipate insiders to sell mainly before poor future performance.

\section{A. Distribution of Net Insider Selling around RTO Announcements as a Function of Future Performance}

We first sort the net insider selling into quintiles based on the change in the future industryadjusted operating performance with the bottom quintile representing the most poorly performing firms. ${ }^{10}$ The results are reported in Table IV. Future performance is deemed "inferior," "neutral," or "superior" if it is in the lowest quintile, the middle three quintiles, or the highest quintile of the performance distribution. The post-repurchase announcement net insider selling is the strongest when forthcoming operating performance is the lowest (i.e., inferior). The average net insider selling in the quarter immediately after the repurchase announcement (Quarter 0) is

\footnotetext{
${ }^{10}$ Our operating performance measure is described in Section II.B. We perform all the sorting in the paper separately within Dutch auction and fixed price tender offers.
} 
$3.55 \%$ of shares outstanding for the firms with the worst forthcoming earnings (as compared to $0.05 \%$ and $0.47 \%$ for the four quarters prior to and the four quarters subsequent to the quarter immediately after the RTO announcement, respectively). While most of the selling takes place in the quarter immediately after the repurchase announcement (Quarter 0), there is some evidence of selling in Quarter +3 for the firms with the worst forthcoming earnings. ${ }^{11}$ For these firms, the average net insider selling in this quarter is $1.35 \%$ of shares outstanding for the most underperforming firms. Overall, the results are consistent with insiders trading on forthcoming earnings information. However, there is some evidence that insiders also sell in the quarter immediately after the repurchase announcement even when future earnings performance is high. The average net insider selling in the quarter immediately after the repurchase announcement is $1.63 \%$ and $1.37 \%$ for the middle quintiles and the top quintile of the post-repurchase change in the industry-adjusted ROA, respectively. This result suggests that some managers could trade for liquidity reasons, where they time the repurchase signal with their stock sales to increase their selling price. Untabulated results indicate that the findings are driven by the selling side of the net selling.

We then sort the net insider selling into quintiles based on the three-year future abnormal stock returns after the repurchase announcement, with the bottom quintile representing the most overvalued firms and the top quintile representing the most undervalued firms. ${ }^{12}$ We use a three-year return horizon instead of a shorter horizon for two reasons. First, potential downward price pressure created by insider selling could bias the association between abnormal returns and insider trading. Insider trading could affect stock performance in the short run as it may signal insiders' private information. However, in the long run, stock performance should be driven by the underlying economic performance and new information about the firm and not by insider trading. We expect the three-year abnormal return to be associated with insider trading only to the extent that insider trading anticipates the forthcoming new information. Second, insiders could distance their trade from future realizations of underperformance (Ke, Huddart, and Petroni, 2003). Executing large insider sales immediately before negative returns could increase the probability of litigation.

The distribution of net insider selling around the repurchase announcement as a function of the abnormal returns in the three years subsequent to the announcement month is also reported in Table IV. The results are consistent with those obtained when we sort on forthcoming earnings. They suggest that post-repurchase net insider selling is the strongest when firms are overvalued. The average net insider selling in the quarter immediately after the repurchase announcement (Quarter 0) is $3.25 \%$ of shares outstanding for the most overvalued firms (as compared to $0.06 \%$ and $0.32 \%$ for the four quarters preceding and the four quarters subsequent to the quarter immediately after the RTO announcement, respectively). This result is consistent with insiders trading on their private information. However, we again find some evidence that insiders also sell even when the post-repurchase abnormal return is high. The average net insider selling is $1.74 \%$ and $1.33 \%$ for the middle quintiles and the top quintile of the long-term abnormal returns, respectively. Again, the results are driven by the selling side of the net trading.

\footnotetext{
${ }^{11}$ As mentioned earlier, trading in the months immediately following repurchase announcements may be optimal for informed traders who want to distance their selling as much as possible from forthcoming disappointing earnings and/or returns. However, some informed managers might want to distance their selling activities from the repurchase announcement. Some could also obtain information about the forthcoming performance months after the repurchase announcement. Nonetheless, the reason for the timing of the selling activities is not obvious.

${ }^{12}$ Our long-term abnormal return measure is described in Section II.C.
} 
We then condition the association between net insider selling and future performance on the type of the RTO. The results are presented in Table V. Panel A reports results for Dutch auction repurchases and Panel B reports results for fixed price repurchases. We find that for Dutch auction tender offers, net insider selling is the strongest when future performance is most

\section{Table V. Mean Percentage of Net Insider Selling as a Function of Future Performance Conditional on the Type of Repurchase Tender Offer}

This table presents the association between net insider selling in the quarters surrounding repurchase announcements and performance over the three years following the repurchase announcement month. Future performance is deemed "inferior," "neutral," or "superior" if it is in the lowest quintile, the middle three quintiles, or the highest quintile of the performance distribution. $\triangle A D J \_R O A 3$ and LTABRET3 are defined as in Table I. $Q_{-4}, \ldots, Q_{0}, \ldots$, and $Q_{+4}$ are the fourth quarter before the repurchase announcement, ..., the quarter (91 days) that immediately follows the repurchase announcement, ..., and the fourth quarter after the quarter that immediately follows the repurchase announcement, respectively.

\begin{tabular}{|c|c|c|c|c|c|c|}
\hline \multicolumn{7}{|c|}{ Panel A. Dutch Auction RTO $(N=163)$} \\
\hline \multirow[t]{2}{*}{ Quarter } & \multicolumn{3}{|c|}{$\begin{array}{l}\text { Future Operating Performance } \\
\left(\triangle A D J \_R O A 3\right)\end{array}$} & \multicolumn{3}{|c|}{$\begin{array}{l}\text { Future Stock Performance } \\
\text { (LTABRET3) }\end{array}$} \\
\hline & $\begin{array}{l}\text { Inferior } \\
(N=54)\end{array}$ & $\begin{array}{l}\text { Neutral } \\
(N=164)\end{array}$ & $\begin{array}{l}\text { Superior } \\
(N=54)\end{array}$ & $\begin{array}{l}\text { Inferior } \\
(N=54)\end{array}$ & $\begin{array}{l}\text { Neutral } \\
(N=164)\end{array}$ & $\begin{array}{l}\text { Superior } \\
(N=54)\end{array}$ \\
\hline$\overline{Q_{-4}}$ & 0.032 & 0.070 & 0.171 & 0.070 & 0.062 & 0.158 \\
\hline$Q_{-3}$ & 0.078 & 0.005 & 0.022 & 0.055 & 0.017 & 0.007 \\
\hline$Q_{-2}$ & 0.078 & 0.018 & 0.000 & 0.031 & 0.031 & 0.007 \\
\hline$Q_{-1}$ & 0.084 & 0.021 & 0.013 & 0.043 & 0.031 & 0.022 \\
\hline$Q_{0}$ & 4.058 & 0.379 & 0.815 & 3.451 & 0.576 & 0.812 \\
\hline$Q_{+1}$ & 0.104 & 0.025 & 0.098 & -0.016 & 0.081 & 0.043 \\
\hline$Q_{+2}$ & 0.404 & -0.026 & 0.584 & 0.557 & 0.102 & 0.034 \\
\hline$Q_{+3}$ & 2.243 & 0.040 & 0.043 & -0.008 & 0.774 & 0.025 \\
\hline$Q_{+4}$ & 0.314 & 0.079 & 0.193 & 0.352 & 0.040 & 0.278 \\
\hline Mean: $Q_{-4}$ to $Q_{-1}$ & 0.068 & 0.029 & 0.052 & 0.050 & 0.035 & 0.049 \\
\hline Mean: $Q_{+1}$ to $Q_{+4}$ & 0.766 & 0.030 & 0.230 & 0.221 & 0.249 & 0.095 \\
\hline Mean: $Q_{-4}$ to $Q_{+4}$ & 0.822 & 0.068 & 0.215 & 0.504 & 0.190 & 0.154 \\
\hline
\end{tabular}

Panel B. Fixed Price RTO $(N=111)$

\begin{tabular}{|c|c|c|c|c|c|c|}
\hline \multirow[t]{2}{*}{ Quarter } & \multicolumn{3}{|c|}{$\begin{array}{l}\text { Future Operating Performance } \\
\left(\triangle A D J \_R O A 3\right)\end{array}$} & \multicolumn{3}{|c|}{$\begin{array}{c}\text { Future Stock Performance } \\
\text { (LTABRET3) }\end{array}$} \\
\hline & $\begin{array}{l}\text { Inferior } \\
(N=22)\end{array}$ & $\begin{array}{l}\text { Neutral } \\
(N=67)\end{array}$ & $\begin{array}{l}\text { Superior } \\
(N=22)\end{array}$ & $\begin{array}{l}\text { Inferior } \\
(N=22)\end{array}$ & $\begin{array}{l}\text { Neutral } \\
(N=67)\end{array}$ & $\begin{array}{l}\text { Superior } \\
(N=22)\end{array}$ \\
\hline$\overline{Q_{-4}}$ & 0.013 & 0.104 & 0.230 & 0.072 & 0.015 & 0.442 \\
\hline$Q_{-3}$ & 0.025 & -0.074 & 0.038 & 0.013 & -0.035 & -0.070 \\
\hline$Q_{-2}$ & 0.008 & -0.400 & 0.201 & 0.166 & -0.389 & 0.012 \\
\hline$Q_{-1}$ & 0.011 & 0.286 & -0.274 & 0.022 & 0.284 & -0.277 \\
\hline$Q_{0}$ & 2.799 & 3.472 & 2.188 & 2.953 & 3.458 & 2.079 \\
\hline$Q_{+1}$ & 0.023 & 0.280 & 0.069 & 1.604 & -0.229 & 0.040 \\
\hline$Q_{+2}$ & -0.027 & 0.052 & 0.378 & 0.159 & -0.014 & 0.394 \\
\hline$Q_{+3}$ & 0.043 & -0.016 & 0.179 & 0.014 & 0.002 & 0.154 \\
\hline$Q_{+4}$ & 0.087 & 0.167 & 0.102 & 0.029 & 0.181 & 0.116 \\
\hline Mean: $Q_{-4}$ to $Q_{-1}$ & 0.014 & -0.021 & 0.049 & 0.068 & -0.031 & 0.027 \\
\hline Mean: $Q_{+1}$ to $Q_{+4}$ & 0.032 & 0.121 & 0.182 & 0.452 & -0.015 & 0.176 \\
\hline Mean: $Q_{-4}$ to $Q_{+4}$ & 0.331 & 0.430 & 0.346 & 0.559 & 0.364 & 0.321 \\
\hline
\end{tabular}


negative, whether we use operating performance or abnormal stock return. Interestingly, for fixed price tender offers, we find no indication that net insider selling is related to future performance. ${ }^{13}$ Therefore, overall, the evidence suggests that the negative association between net insider selling and future performance is driven by Dutch auction tender offers.

\section{B. Regression Analysis}

We now analyze the association between net insider selling and future performance, conditional on other factors that could affect insider trading. We create a binary variable, Poorest_PERF, for poor future performance where Poorest_PERF is assigned the value one for firms in the bottom quintile of future performance and zero otherwise. We use a binary variable since the evidence in Table $\mathrm{V}$ indicates that the association between net insider selling and future performance for Dutch auction tender offers is nonlinear (with most of the selling concentrated in those firms in the bottom quintile of future performance). More specifically, we use the following model:

$$
\begin{aligned}
\operatorname{ADJNIT}_{i}= & \alpha_{0}+\alpha_{1} \text { Poorest_PERF }_{i}+\alpha_{2} \text { CAR }_{i}+\alpha_{3} \text { LSHR_REP }_{i} \\
& +\alpha_{4} \text { SIZE }_{i}+\alpha_{5} \text { BMQ }_{i}+e_{i},
\end{aligned}
$$

where $A D J N I T$ is either net insider trading (selling) in the quarter immediately after the repurchase announcement (i.e., Quarter 0) minus the average net insider trading over the four quarters before the repurchase announcement or net insider trading over the four quarters after the repurchase announcement (i.e., Quarter 0 through Quarter +3 ) minus net insider trading over the four quarters before the repurchase announcement, Poorest_PERF is a binary variable taking the value of one for firms in the lowest quintile of the distribution of performance over the three years subsequent to the repurchase announcement month and zero otherwise, $C A R$ is the market-adjusted returns over the three days centered on the repurchase announcement date and zero otherwise, LSHR_REP is the logarithm of the percentage of shares repurchased and zero otherwise, SIZEQ is size quintile, where size is the market value of equity at the beginning of the fiscal quarter prior to the repurchase announcement, and $B M Q$ is book-to-market quintile, where book-to-market is the ratio of common book equity to total market capitalization at the beginning of the fiscal quarter prior to the repurchase announcement.

As explained earlier, we expect a positive association between Poorest_PERF and insider trading (i.e., $\alpha_{1}>0$ ) if insider trading after the repurchase announcement is based on private information. It should be noted that while the market reaction to the repurchase may contribute to overvaluation, informed investors are likely to base their trading decision on their actual assessment of mispricing instead of the market reaction. The market reaction does not even have to be correlated with the mispricing. For instance, the repurchase announcement abnormal return could be $15 \%$ for Firm A and 10\% for Firm B. However, the market reaction for Firm A may be warranted whereas the reaction for Firm B may not. It is even plausible that Firm B (or Firm A, for that matter) was mispriced even before the repurchase announcement and that the repurchase simply makes the trading opportunity more attractive. In any case, informed traders will decide whether to trade based on the extent to which they perceive that a firm is mispriced, not on the market reaction to the repurchase announcement.

We control for the market reaction to the repurchase announcement, $C A R$, since managers who intend to sell large amounts of shares could strengthen the repurchase signal by using

\footnotetext{
${ }^{13}$ The difference in net insider selling between firms with "inferior" performance and those in the other two categories is statistically significant for Dutch auction tender offers and not for fixed price tender offers.
} 
mechanisms such as the stated reason for the repurchase and/or the strength of the language used in the repurchase announcement press release. Therefore, we expect a positive relation between the market reaction and net insider selling. The market reaction could also be negatively correlated with insider selling if the market views the selling by insiders as an indication that they have negative private information about the firms' future prospects and, hence, reacts negatively. However, at the time of the repurchase announcement, the market generally does not know how many shares the managers intend to sell over the following quarter. It should also be noted that we measure insider trading after the repurchase announcement.

We control for the share of the company repurchased, $L S H R \_R E P$. On the one hand, managers could tender in the repurchase to convince investors that the offering price is fair. The rationale is that if the managers do not sell any shares, after the repurchase they will own a larger proportion of the firm as the number of shares outstanding decreases. To convince investors to tender their shares, managers could also have to tender a portion of their own holdings. Otherwise, investors could interpret the managers' decision not to tender their shares as an indication that they have private information about the firm's future performance that justifies a higher price than what they offer. ${ }^{14}$ We would expect the number of shares they tender to increase in the size of the repurchase. Conversely, by tendering their shares, managers might send a negative signal about their beliefs regarding the firm's future prospects. If managers want to send a strong favorable signal about the firm's future performance, then they may choose not to tender their shares, which could dampen the potential relation between insider trading and the percentage of shares repurchased.

We also include $S I Z E Q$ and $B M Q$ in the model. We control for size since liquidity traders, in particular, are likely to sell a larger portion of the firm on personal accounts to satisfy their needs when the firm is small. The book-to-market ratio controls for the effect documented by Rozeff and Zaman (1998) that insider buying increases as stocks change from growth to value categories.

We report the association between net insider selling and poor future performance in Table VI. The results for Dutch auction tender offers are reported in Panel A and the results for fixed price tender offers are reported in Panel B. For Dutch auction tender offers, the coefficients on Poorest_PERF are significantly positive whether we use earnings or stock returns to define performance, which is consistent with insiders trading opportunistically on their private information about the firms' future prospects. In contrast, we find no significant association between net insider selling and Poorest_PERF for fixed price tender offers. ${ }^{15}$ In general, we also find a positive association between net insider selling and the share of the company brought back in the repurchase. Winsorizing the top and bottom one percentiles of ADJNIT does not qualitatively change the results. The results are generally qualitatively similar if we restrict insider

\footnotetext{
${ }^{14}$ Managers may choose not to tender their shares to convince investors that they are optimistic about the future. However, they face the risk of raising investors' expectations too high. Tendering their own shares at the offering price is probably the best way to convince investors that the tender premium is not too low.

${ }^{15}$ We intended to address two related questions. First, do insiders trade on their private information within each type of tender offer? Second, are informed traders more likely to sell after a Dutch auction RTO than after a fixed price tender offer? Untabulated results provide no evidence of a statistically significant difference in the relation between insider trading and future performance across Dutch auction tender offers and fixed price tender offers. The failure to document a statistical difference across the two types of repurchases is likely due to a lack of power related to our limited sample size. Our test allows us to make inferences only about the first question. The coefficient on Poorest_PERF is significant for Dutch auction RTOs (with one-tail $p$-values generally below 0.01 ), whereas it is very insignificant for fixed price RTOs (one-tail (two-tail) $p$-values ranging from 0.275 to 0.462 ( 0.550 to 0.924$)$ ). Therefore, there is evidence of informed trading after Dutch auction tender offers and not after fixed priced tender offers. Note that in conducting this analysis, we estimate the model separately for each of the two types of repurchases as opposed to estimating it as a pooled regression.
} 
Table VI. Association between Net Insider Selling after Repurchase Tender Offer Announcements and Future Performance

$$
\text { ADJNIT }_{i}=\alpha_{0}+\alpha_{1} \text { Poorest_PERF }_{i}+\alpha_{2} \text { CAR }_{i}+\alpha_{3} L S H R \_R E P_{i}+\alpha_{4} S I Z E Q_{i}+\alpha_{5} B M Q_{i}+e_{i} .
$$

In Model 1, ADJNIT is net insider trading (expressed as a percentage of shares outstanding) in the quarter immediately after the repurchase announcement minus the average net insider trading over the four quarters before the repurchase announcement; in Model 2, ADJNIT is net insider trading (expressed as a percentage of shares outstanding) over the four quarters after the repurchase announcement minus net insider trading over the four quarters before the repurchase announcement, Poorest_PERF is a binary variable taking the value one for firms in the lowest quintile of the distribution of performance over the three years subsequent to the repurchase announcement month and zero otherwise, $C A R$ is the market-adjusted returns over the three days centered on the repurchase announcement date and zero otherwise, LSHR_REP is the logarithm of the percentage of shares repurchased and zero otherwise, SIZEQ is size quintile where size is the market value of equity at the beginning of the fiscal quarter prior to the repurchase announcement, and $B M Q$ is book-to-market quintile where book-to-market is the ratio of common book equity to total market capitalization at the beginning of the fiscal quarter prior to the repurchase announcement. One-tail $p$-values are reported in brackets and two-tail $p$-values are reported in parentheses.

\begin{tabular}{|c|c|c|c|c|c|}
\hline \multirow[b]{2}{*}{ Coefficient } & \multirow[b]{2}{*}{ Variable } & \multicolumn{2}{|c|}{$\begin{array}{c}\text { Performance is Measured } \\
\text { as the Change in } \\
\text { Return on Assets (ROA) } \\
\text { over the Three Years } \\
\text { after the Repurchase }\end{array}$} & \multicolumn{2}{|c|}{$\begin{array}{c}\text { Performance is Measured } \\
\text { as Abnormal Stock } \\
\text { Return over the } \\
\text { Three Years after } \\
\text { the Repurchase }\end{array}$} \\
\hline & & Model 1 & Model 2 & Model 1 & Model 2 \\
\hline \multicolumn{6}{|c|}{ Panel A. Dutch Auction Repurchase Tender Offers $(N=163)$} \\
\hline$\alpha_{0}$ & Intercept & $\begin{array}{c}4.337 \\
(0.058)\end{array}$ & $\begin{array}{c}0.144 \\
(0.850)\end{array}$ & $\begin{array}{c}3.904 \\
(0.091)\end{array}$ & $\begin{array}{c}0.157 \\
(0.961)\end{array}$ \\
\hline$\alpha_{1}$ & Poorest_PERF & $\begin{array}{c}3.083 \\
{[0.009]}\end{array}$ & $\begin{array}{c}1.407 \\
{[0.001]}\end{array}$ & $\begin{array}{c}3.095 \\
{[0.009]}\end{array}$ & $\begin{array}{c}0.733 \\
{[0.050]}\end{array}$ \\
\hline$\alpha_{2}$ & $C A R$ & $\begin{array}{c}5.896 \\
{[0.159]}\end{array}$ & $\begin{array}{c}1.992 \\
{[0.156]}\end{array}$ & $\begin{array}{c}6.868 \\
{[0.122]}\end{array}$ & $\begin{array}{c}2.435 \\
{[0.114]}\end{array}$ \\
\hline$\alpha_{3}$ & $L S H R \_R E P$ & $\begin{array}{c}2.452 \\
{[0.001]}\end{array}$ & $\begin{array}{c}0.225 \\
{[0.201]}\end{array}$ & $\begin{array}{c}2.576 \\
{[0.001]}\end{array}$ & $\begin{array}{c}0.278 \\
{[0.313]}\end{array}$ \\
\hline$\alpha_{4}$ & SIZEQ & $\begin{array}{c}0.065 \\
{[0.429]}\end{array}$ & $\begin{array}{c}0.047 \\
{[0.351]}\end{array}$ & $\begin{array}{c}0.227 \\
{[0.267]}\end{array}$ & $\begin{array}{c}0.103 \\
{[0.157]}\end{array}$ \\
\hline$\alpha_{5}$ & $B M Q$ & $\begin{array}{c}0.473 \\
{[0.098]}\end{array}$ & $\begin{array}{c}0.117 \\
{[0.169]}\end{array}$ & $\begin{array}{c}0.618 \\
{[0.047]}\end{array}$ & $\begin{array}{c}0.160 \\
{[0.103]}\end{array}$ \\
\hline Adj. $R^{2}$ & & 0.092 & 0.061 & 0.092 & 0.013 \\
\hline \multicolumn{6}{|c|}{ Panel B. Fixed Price Repurchase Tender Offers $(N=111)$} \\
\hline$\alpha_{0}$ & Intercept & $\begin{array}{c}6.325 \\
(0.121)\end{array}$ & $\begin{array}{c}1.785 \\
(0.125)\end{array}$ & $\begin{array}{c}6.518 \\
(0.101)\end{array}$ & $\begin{array}{c}1.688 \\
(0.135)\end{array}$ \\
\hline$\alpha_{1}$ & Poorest_PERF & $\begin{array}{c}1.384 \\
{[0.326]}\end{array}$ & $\begin{array}{c}0.226 \\
{[0.398]}\end{array}$ & $\begin{array}{c}1.259 \\
{[0.326]}\end{array}$ & $\begin{array}{c}0.658 \\
{[0.203]}\end{array}$ \\
\hline$\alpha_{2}$ & $C A R$ & $\begin{array}{c}4.843 \\
{[0.238]}\end{array}$ & $\begin{array}{c}1.155 \\
{[0.255]}\end{array}$ & $\begin{array}{c}4.626 \\
{[0.246]}\end{array}$ & $\begin{array}{c}1.169 \\
{[0.271]}\end{array}$ \\
\hline$\alpha_{3}$ & $L S H R \_R E P$ & $\begin{array}{c}2.868 \\
{[0.025]}\end{array}$ & $\begin{array}{c}0.844 \\
{[0.022]}\end{array}$ & $\begin{array}{c}2.855 \\
{[0.025]}\end{array}$ & $\begin{array}{c}0.846 \\
{[0.021]}\end{array}$ \\
\hline$\alpha_{4}$ & SIZEQ & $\begin{array}{c}0.706 \\
{[0.209]}\end{array}$ & $\begin{array}{c}0.177 \\
{[0.239]}\end{array}$ & $\begin{array}{c}0.584 \\
{[0.233]}\end{array}$ & $\begin{array}{c}0.170 \\
{[0.228]}\end{array}$ \\
\hline$\alpha_{5}$ & $B M Q$ & $\begin{array}{c}-0.441 \\
{[0.709]}\end{array}$ & $\begin{array}{c}-0.051 \\
{[0.589]}\end{array}$ & $\begin{array}{c}-0.399 \\
{[0.701]}\end{array}$ & $\begin{array}{c}-0.038 \\
{[0.567]}\end{array}$ \\
\hline Adj. $R^{2}$ & & 0.011 & 0.009 & 0.011 & 0.015 \\
\hline
\end{tabular}


trading to trading by the top five executives, officers, and directors with substantial ownership and controlling shareholders.

We also estimate Equation (2) with executive stock ownership as a control variable. Adding executive stock ownership to the model does not qualitatively change the results. Untabulated results indicate that for the 94 Dutch auction tender offers, the coefficients (one-tail $p$-values) on Poorest_PERF are 3.091 (0.080) using stock returns to define performance and 5.740 (0.004) using earnings to define performance if $A D J N I T$ is measured in Quarter 0 and we include the executives' total stock ownership as a control variable. If we include the average executive stock ownership in each firm, the coefficients (one-tail $p$-values) are $3.415(0.060)$ when we use stock returns to define performance and $5.882(0.004)$ when we use earnings to define performance. The coefficient is only marginally significant when we use stock returns to define performance; however, the magnitudes of the coefficients are almost the same as those reported in Table VI. Consistent with the results in Table VI, we find no evidence of a significant association between Poorest_PERF and insider trading for the 42 fixed price repurchase observations that have executive ownership data, whether we control for executive ownership or not.

Taken together, the evidence suggests that net insider trading after Dutch auction tender offers is more likely to be driven by informed trading whereas net insider trading after fixed price tender offers is more likely to be driven by liquidity trading. As explained earlier, this notion is based on the observation that for Dutch auction tender offers, net insider selling after the repurchase announcement is concentrated largely among firms that subsequently perform poorly. In addition, this pattern is observed almost exclusively in the quarter after the repurchase announcement. There is no particular indication of any such pattern prior to the repurchase announcement. In contrast, for fixed price tender offers, we find no clear indication that the selling is associated with future performance. Our inference is further supported by the observation that 1) the average percentage of shares repurchased and the market reaction to the repurchase announcement are significantly larger for fixed price tender offers than for Dutch auction tender offers and 2) there is a very strong concentration of insider selling in the quarter after fixed price tender offer announcements, although there is no indication that the selling is related to future performance. However, we do not contend that all insider selling around fixed price repurchases is driven by liquidity trading or that all insider selling around Dutch auction repurchases is driven by informed trading. For instance, the observation that, on average, insiders sell a substantial number of shares after Dutch auction tender offer announcements even when the firms subsequently experience superior performance suggests that there is some liquidity trading associated with Dutch auction RTO announcements.

\section{Conclusion}

Abnormally high net insider selling has been documented after RTO announcements even though firms, on average, experience positive abnormal returns in the years following the repurchases. In this study, we test two alternative hypotheses for this somewhat counterintuitive trading pattern. Under the first hypothesis, insiders trading for liquidity reasons time their selling activities with the repurchases to minimize potential undervaluation, thereby maximizing their selling price. Under the second hypothesis, insiders trading on their private information sell shares in response to overpricing due to the market misinterpreting the degree to which certain repurchases act as signals of undervaluation.

The repurchase literature suggests that a repurchase announcement serves as a signal to the market that the stock is undervalued. Moreover, prior studies find that firms experience positive average abnormal returns after RTO announcements. However, we find that about half of the 
repurchasing firms experience negative long-term abnormal returns, suggesting that some of the positive market reactions to repurchase announcements could be unwarranted. We posit that some managers could use repurchases for purposes other than signaling and yet investors misinterpret them as signals of managerial optimism. Therefore, they could overprice the shares allowing insiders to exploit their private information by selling shares at inflated prices.

We find evidence that managers sell substantial amounts of shares in the quarter immediately following RTO announcements. We further find a significantly negative association between net insider selling and both future operating and stock performance. This result suggests that RTOs probably afford insiders opportunities to extract rents by taking advantage of their private information about their firms' prospects. However, we also find substantial insider selling even among the firms that subsequently experience strong performance, suggesting that not all insider trading after RTO announcements is driven by informed traders.

After partitioning the sample on the tender offer mechanism, we find that the significantly negative association between net insider selling and future long-term performance documented for the full sample is driven by firms engaging in Dutch auction tender offers. Consistent with the conjecture that fixed price tender offers are more likely to be associated with signaling than Dutch auction tender offers, we find no evidence that insider selling is significantly associated with future performance for firms engaging in fixed price tender offers even though insider selling is generally very high after fixed price tender offer announcements. In sum, it appears that insider selling after Dutch auction tender offers is largely driven by informed traders who exploit investor mispricing, whereas insider selling after fixed price tender offer announcements is largely driven by liquidity traders who time the repurchase announcements with their selling to mitigate potential undervaluation.

\section{References}

Asquith, P. and D. Mullins, 1986, "Signaling with Dividends, Stock Repurchases, and Equity Issues," Financial Management 15, 27-44.

Bettis, C., J. Coles, and M. Lemmon, 2000, “Corporate Policies Restricting Trading by Insiders," Journal of Financial Economics 57, 191-220.

Bhattacharya, S., 1979, "Imperfect Information, Dividend Policy, and 'the Bird in the Hand' Fallacy," Bell Journal of Economics 10, 259-270.

Brav, A., J. Graham, C. Harvey, and R. Michaely, 2005, "Payout Policy in the 21st Century," Journal of Financial Economics 77, 483-527.

Brennan, M. and A. Thakor, 1990, "Shareholder Preferences and Dividend Policy," Journal of Finance 4, 993-1018.

Comment, R. and G. Jarrell, 1991, "The Relative Signaling Power of Dutch Auction and Fixed Price Self-Tender Offers and Open-Market Share Purchases," Journal of Finance 46, 1243-1271.

Constantinides, G. and B. Grundy, 1989, “Optimal Investment with Stock Repurchase and Financing as Signals," Review of Financial Studies 2, 445-465.

Daniel, K., M. Grinblatt, S. Titman, and R. Wermers, 1997, "Measuring Mutual Fund Performance with Characteristics-Based Benchmarks," Journal of Finance 52, 1035-1058.

Dann, L., 1981, “Common Stock Repurchases: An Analysis of Returns to Bondholders and Stockholders," Journal of Financial Economics 9, 113-138. 
Dann, L., R. Masulis, and D. Mayers, 1991, "Repurchase Tender Offers and Earnings Information," Journal of Accounting and Economics 14, 217-251.

D’Mello, R. and P. Shroff, 2000, “Equity Undervaluation and Decisions Related to Repurchase Tender Offers: An Empirical Investigation,” Journal of Finance 55, 2399-2424.

Fried, J., 2000, "Insider Signaling and Insider Trading with Repurchase Tender Offers," University of Chicago Law Review 67, 421-478.

Fried, J., 2001, “Open Market Repurchases: Signaling or Managerial Opportunism?” Theoretical Inquiries in Law (Online Edition) 2, Article 11.

Gay, G., J. Kale, and T. Noe, 1991, "Share Repurchase Mechanisms: A Comparative Analysis of Efficacy, Shareholder Wealth, and Corporate Control Effects," Financial Management 20, 44-59.

Gibbons, R. 2005, "Share Buybacks Aren’t All Equal,” Motleyfool.com. Available at: http:// www.fool.com/news/commentary/2005/commentary05091607.htm.

Graham, J., C. Harvey, and S. Rajgopal, 2005, "The Economic Implications of Corporate Financial Reporting," Journal of Accounting and Economics 40, 3-73.

Grullon, G. and D. Ikenberry, 2000, “What Do We Know about Stock Repurchases?” Journal of Applied Corporate Finance 13, 31-51.

Grullon, G. and R. Michaely, 2004, “The Information Content of Share Repurchase Programs," Journal of Finance 49, 651-680.

Hausch, D. and J. Seward, 1993, "Signaling with Dividends and Share Repurchases: A Choice between Deterministic and Stochastic Cash Disbursements," Review of Financial Studies 6, 121-154.

Henry, D., 2004, "Why the Flurry of Buybacks?" Businessweek Online, November 29. Available at: http://www.businessweek.com/magazine/content/04_48/b3910104_mz020.htm.

Hribar, S., W. Johnson, and N. Jenkins, 2006, "Stock Repurchases as an Earnings Management Device," Journal of Accounting and Economics 41, 3-37.

Hyatt, J., 1988, "Schlumberger to Buy at Most 30 Million Shares," Wall Street Journal, September 20.

Jolls, C., 1998, “Stock Repurchases and Incentive Compensation,” NBER Working Paper No. W6467. Available at SSRN: http://ssrn.com/abstract=226212.

Kahle, K., 2002, "When a Buyback Isn't a Buyback: Open-Market Repurchases and Employee Options," Journal of Financial Economics 63, 235-261.

Kaye, M., 2005, “A Boost from the Buyback Binge?” Businessweek Online, June 10. Available at: http://www.businessweek.com/investor/content/jun2005/pi20050610_0261_pi012.htm.

Ke, B., S. Huddart, and K. Petroni, 2003, "What Insiders Know about Future Earnings and How They Use It: Evidence from Insider Trades,” Journal of Accounting and Economics 35, 315-346.

Lakonishok, J. and I. Lee, 2001, “Are Insiders’ Trades Informative?” Review of Financial Studies 14, 79-111.

Lakonishok, J. and T. Vermaelen, 1990, “Anomalous Price Behavior Around Repurchase Tender Offers," Journal of Finance 45, 455-477.

Lane, W., S. Sarker, and J. Wansley, 1989, “Managements' View on Share Repurchase and Tender Offer Premiums," Financial Management 18, 97-110.

Lee, S., W. Mikkelson, and M. Partch, 1992, “Manager's Trading Around Stock Repurchases," Journal of Finance 47, 1947-1961. 
Lie, E. and J. McConnell, 1998, "Earnings Signals in Fixed Price and Dutch Auction Self-Tender Offers," Journal of Financial Economics 49, 161-186.

Louis, H. and H. White, 2007, "Do Managers Intentionally Use Repurchase Tender Offers to Signal Private Information? Evidence from Firm Financial Reporting Behavior," Journal of Financial Economics 85, 205-233.

Maxwell, W. and C. Stephens, 2003, “The Wealth Effects of Repurchases on Bondholders," Journal of Finance 58, 895-920.

Nayar, N., A. Singh, and A. Zebedee, 2008, "Share Repurchase Offers and Liquidity: An Examination of Temporary and Permanent Effects," Financial Management 37, 251-270.

Ofer, A. and V. Thakor, 1987, "A Theory of Stock Price Responses to Alternative Corporate Cash Disbursements Methods: Stock Repurchase and Dividends," Journal of Finance 42, 365-394.

Opdyke, J., 1998, “Insider's View: Firms Planning Buybacks Make a Profitable Bet," Wall Street Journal, April 1, T.2.

Persons, J., 1994, "Signaling and Takeover Deterrence with Stock Repurchases: Dutch Auctions versus Fixed Price Tender Offers," Journal of Finance 49, 1373-1402.

Persons, J., 1997, "Heterogeneous Shareholders and Signaling with Share Repurchases," Journal of Corporate Finance 3, 221-249.

Pettit, R., Y. Ma, and J. He, 1996, "Do Corporate Insiders Circumvent Insider Trading Regulations? The Case of Stock Repurchases," Review of Quantitative Finance and Accounting 7, 81-96.

Peyer, U. and T. Vermaelen, 2008, "The Nature and Persistence of Buyback Anomalies," Review of Financial Studies 22, 1693-1745.

Rozeff, M.S. and M.A. Zaman, 1998, "Overreaction and Insider Trading: Evidence from Growth and Value Portfolios," Journal of Finance 53, 701-716.

Vermaelen, T., 1981, "Common Stock Repurchases and Market Signalings," Journal of Financial Economics 9, 139-183.

Vermaelen, T., 1984, "Repurchase Tender Offers, Signaling, and Managerial Incentives," Journal of Financial and Quantitative Analysis 19, 163-181. 